\title{
Preliminary Characterization of Calcium Binding in Islet-cell Plasma Membranes
}

\author{
S. P. Naber, J. M. McDonald, L. Jarett, M. L. McDaniel, C. W. Ludvigsen, and P. E. Lacy \\ Department of Pathology, Washington University School of Medicine, St. Louis, Missouri, USA
}

Summary. Preliminary characterization of calcium binding was determined in a highly-enriched islet-cell plasma membrane fraction using a membrane filtration technique. Equilibrium calcium binding was specific, concentration dependent and saturable. Scatchard analysis indicated the existence of more than one class of calcium binding sites. The affinity constants and maximum binding capacities were 1.14 $\times 10^{5} \mathrm{M}^{-1}$ and $1.2 \mathrm{picomol} / \mu \mathrm{g}$ protein and $1.17 \times$ $10^{3} \mathrm{M}^{-1}$ and $64.8 \mathrm{picomol} / \mu \mathrm{g}$ for the high and low affinity sites, respectively. Bound ${ }^{45} \mathrm{Ca}^{2+}$ was dissociated from the plasma membranes in a biphasic manner in the presence of excess unlabelled calcium.

Key words: Islets of Langerhans, plasma membrane, calcium binding, ${ }^{45}$ calcium.

The plasma membrane of pancreatic islet cells may participate in the regulation of cation movements involved in insulin secretion. Of particular importance is the regulation of calcium which has been established as an essential requirement for this process [1]. Studies with islets isolated from obesehyperglycemic mice suggest that the islet-cell plasma membrane contains a labile calcium pool which may be involved in the acute regulation of insulin secretion [2]. In addition, ultrastructural studies of pyroantimonate precipitates have indicated localization of calcium at the beta-cell plasma membrane in response to conditions which stimulate insulin release $[3,4]$. Such observations support the general concept that the plasma membrane participates in regulation of the free cytoplasmic calcium level which may link stimulation to secretion in various cells $[5,6]$.

Use of a purified islet-cell plasma membrane fraction provides one means for direct investigation of its calcium handling properties. The purpose of this study, therefore, was to conduct preliminary characterization of calcium binding in a purified, islet-cell plasma membrane fraction. This was done in order to provide a rational basis for further investigations of plasma membrane functions related to islet-cell calcium metabolism and insulin secretion.

\section{Materials and Methods}

\section{Plasma Membrane Isolation}

Islet Isolation. Islets for each experiment were obtained from a single preparation of 15-20 rat pancreata using a modification of the digestion-filtration method of Shibata et al. [7]. Instead of using a single digestion chamber, as originally described, four chambers containing wire mesh screens $(8.0 \times 1.7 \mathrm{~cm}$ diameter $)$ were employed simultaneously to accommodate the large mass of pancreatic tissue during the collagenase digestion. The islets were then separated from the digested tissue by centrifugation $(800 \times$ $\mathrm{g}, 10 \mathrm{~min}$ ) on ten identical discontinuous Ficoll gradients containing $8 \mathrm{ml}$ of $25 \%$, and $4 \mathrm{ml}$ each of $23 \%, 20.5 \%$ and $11 \%$ Ficoll (w/ w). The islets were then harvested from the $20.5 \%-23 \%$ and $11 \%-20.5 \%$ interfaces using a siliconized transfer pipette. In order to remove the Ficoll, the islets were consolidated into a large tube, washed twice $(40 \mathrm{ml}$ each) with ice-cold Hank's solution and centrifuged $(960 \times \mathrm{g}, 2 \mathrm{~min})$ after each wash. A single wash and centrifugation $(960 \times \mathrm{g}, 2 \mathrm{~min}$ ) in $10 \mathrm{ml}$ of ice-cold homogenization buffer (described below) was performed before homogenization.

Homogenization and Centrifugation. A schematic diagram of the islet fractionation procedure is shown in Figure 1. The washed islet pellet was resuspended in $1 \mathrm{ml}$ of ice-cold homogenization buffer containing $50 \mathrm{mmol} / 1 \quad 2$-( $N$-morpholino)ethane sulfonic acid (MES), $\mathrm{pH} 6.0,250 \mathrm{mmol} / 1$ sucrose, and $1 \mathrm{mmol} / 1 \mathrm{EDTA}$ and then transferred to a close-tolerance $(0.05-0.10 \mathrm{~mm})$, Teflonglass, Potter-Elvehjem tíssue grinder (size 19; Kontes Biomedical Products, Vineland, NJ, USA). Islet-cell disruption was accomplished at $0^{\circ} \mathrm{C}$ with 20 strokes of the homogenizer using a motor drive for the pestle at $1170 \mathrm{rpm}$. A $50 \mu \mathrm{l}$ aliquot of the homogenate was removed for assay purposes and the remainder was transferred to a polycarbonate tube $(7.7 \times 1.1 \mathrm{~cm}$ diameter $)$ and centrifuged at $600 \times \mathrm{g}$ for $5 \mathrm{~min}\left(4^{\circ} \mathrm{C}\right)$ in order to remove nuclei and cell debris. The nuclear pellet (P1) was then resuspended in $0.5 \mathrm{ml}$ of homogenization buffer and stored on ice. The supernatant (S1) 


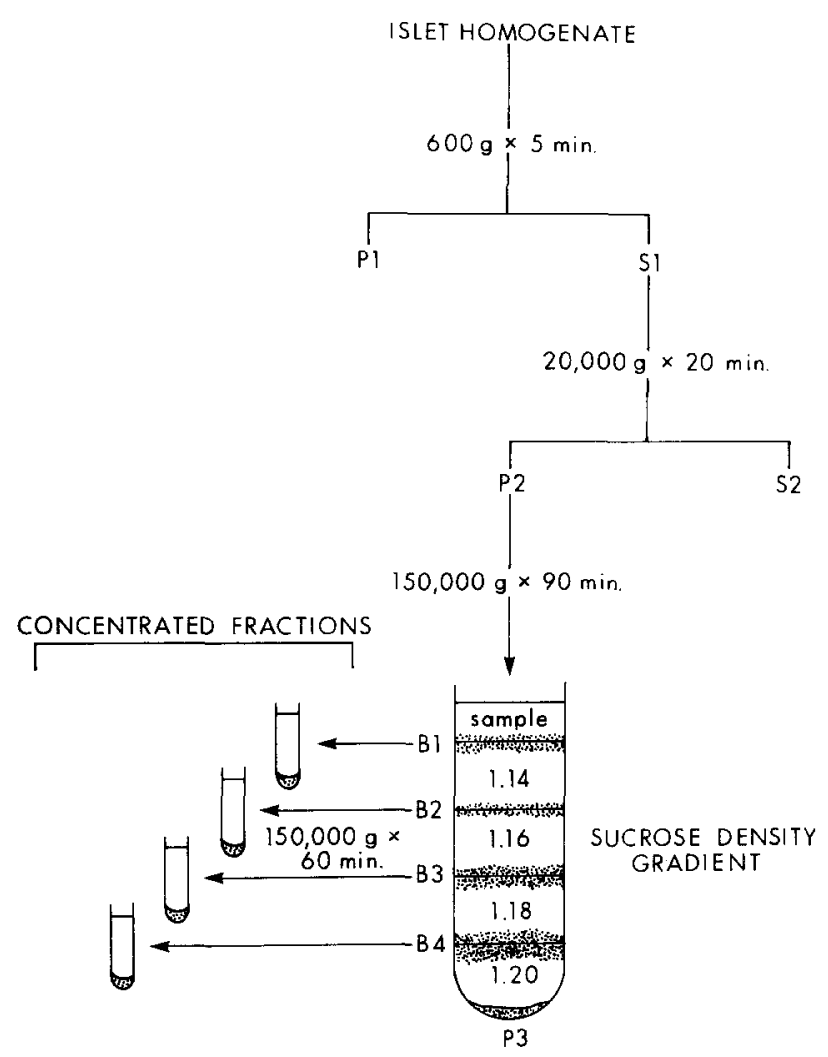

Fig. 1. Flow diagram for the procedure used for fractionation of rat islets

was transferred to a second polycarbonate tube and centrifuged at $20,000 \times \mathrm{g}$ for $20 \mathrm{~min}\left(4^{\circ} \mathrm{C}\right)$ in order to form a crude particulate pellet (P2). P2 was then resuspended in $0.5 \mathrm{ml}$ of centrifugation buffer (10 mmol/1 MES, $\mathrm{pH} 6.0,1 \mathrm{mmol} / 1 \mathrm{EDTA})$ with four strokes of the homogenizer $\left(1170 \mathrm{rpm}, 0-4^{\circ} \mathrm{C}\right)$. A $50 \mu$ aliquot of resuspended $\mathrm{P} 2$ was retained for assay purposes. The remainder of the resuspended pellet was layered on the surface of a discontinous sucrose gradient $(1 \mathrm{ml}$ each of densities $1.14,1.16,1.181 .20$ prepared in centrifugation buffer) prepared at $4{ }^{\circ} \mathrm{C}$ in a nitrocellulose tube $(5.1 \times 1.3 \mathrm{~cm}$ diam., Beckman No. 305050$)$. The gradient was centrifuged at $150,000 \times \mathrm{g}$ for $90 \mathrm{~min}\left(4^{\circ} \mathrm{C}\right)$ in a Beckman L2-65B ultracentrifuge using a SW 50.1 rotor. Four discrete bands (B1-B4) were then removed individually by aspiration with a syringe and needle from the top of each sucrose layer, placed in individual nitrocellulose tubes $(4.2 \times 0.5 \mathrm{~cm}$ diam., Beckman No. 305528), diluted to tube capacity with centrifugation buffer, mixed and centrifuged at $150,000 \times \mathrm{g}$ for $60 \mathrm{~min}$ in order to concentrate the material. The pelleted bands were resuspended in media appropriate for the various biochemical assays.

\section{Analyses}

Protein. The protein content of all fractions was measured by the method of Lowry et al. [8] with bovine serum albumin as standard.

$5^{\prime}$-Nucleotidase. The $5^{\prime}$-nucleotidase (EC 3.1.3.5) was measured by a modification of the technique of Avruch and Wallach [9] Duplicate samples of approximately $10 \mu \mathrm{l}$ of each fraction, containing 2 to $20 \mu \mathrm{g}$ of protein, were each added to $100 \mu \mathrm{l}$ of buffer ( $50 \mathrm{mmol} / 1$ Tris, $\mathrm{pH} 8.4,1.5 \mathrm{mmol} / 1 \mathrm{MgCl}_{2}, 0.12 \mathrm{mg} / \mathrm{ml}$ bovine serum albumin, $\left.0.2 \mathrm{mmol} / 1\left[{ }^{3} \mathrm{H}\right] \mathrm{AMP}, 11.1 \mathrm{MBq} / \mathrm{mmol}\right)$ and incu-

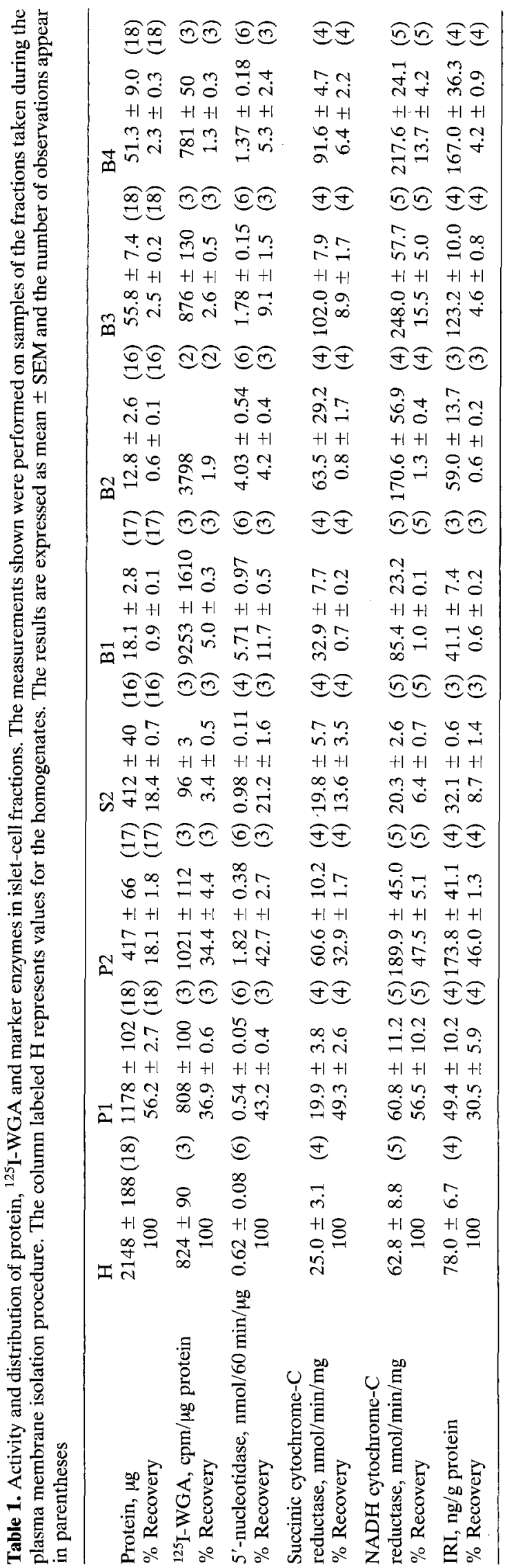


bated for $60 \mathrm{~min}$ at $37^{\circ} \mathrm{C}$ in a $1.5 \mathrm{ml}$ Beckman Microfuge-B tube Incubation was terminated by addition of $20 \mu \mathrm{l}$ of $0.3 \mathrm{~mol} / 1 \mathrm{ZnSO}_{4}$ and $25 \mu \mathrm{l}$ of $0.3 \mathrm{~mol} / \mathrm{l} \mathrm{Ba}(\mathrm{OH})_{2}$ to each tube. Following a 1-min centrifugation in a Beckman Microfuge- $\mathrm{B}$, the same volumes of $0.3 \mathrm{~mol} / 1 \mathrm{ZnSO}_{4}$ and $0.3 \mathrm{~mol} / 1 \mathrm{Ba}(\mathrm{OH})_{2}$ were again added; the mixture was centrifuged for $1 \mathrm{~min}$ and $100-\mu \mathrm{l}$ samples of the supernatants were counted for ${ }^{3} \mathrm{H}$ in a liquid scintillation counter. The 5'-nucleotidase activity was expressed as nmoles AMP hydrolyzed/60 min per $\mu \mathrm{g}$ protein.

${ }^{125}$ I-Wheat Germ Agglutinin Binding. Ovomucoid-Sephadexpurified wheat germ agglutinin (WGA) was kindly provided by $\mathrm{Dr}$. Roslyn Kornfeld of the Hematology Department, Washington University, and was iodinated in our laboratory. The iodination reaction mixture contained $10 \mu \mathrm{g}$ of WGA $(1.3 \mathrm{mg} / \mathrm{ml}), 50 \mu \mathrm{l}$ of $0.3 \mathrm{~mol} / 1$ sodium phosphate buffer, $\mathrm{pH} 7.5$, and $74 \mathrm{MBq}$ of $\mathrm{Na}^{125} \mathrm{I}$. Iodination was accomplished by adding $1 \mu \mathrm{g}$ of freshly prepared chloramine- $\mathrm{T}(50 \mu \mathrm{g} / \mathrm{ml} 0.3 \mathrm{~mol} / \mathrm{l}$ sodium phosphate buffer) to this mixture and allowing the reaction to proceed for $3 \mathrm{~min}$ at room temperature with occasional shaking. The resultant molar ratio of chloramine-T : iodide : WGA was $8.4: 2.2: 1.0$. The iodination reaction was stopped by addition of $2 \mu \mathrm{g}$ of freshly prepared $\mathrm{Na}_{2} \mathrm{~S}_{2} \mathrm{O}_{5}(20 \mu \mathrm{g} / \mathrm{ml} 0.3 \mathrm{~mol} / 1$ sodium phosphate buffer $)$. After $1 \mathrm{~min}, 1 \mathrm{mg}$ of $\mathrm{KI}(10 \mathrm{mg} / \mathrm{ml} 0.3 \mathrm{~mol} / 1$ sodium phosphate buffer) was added and the entire mixture was placed on top of a $0.9 \times$ $18 \mathrm{~cm} \mathrm{G-25}$ Superfine Sephadex column. The ${ }^{125}$ I-WGA was eluted from the column. separate from free iodide, with $0.03 \mathrm{~mol} / 1$ sodium phosphate, $\mathrm{pH} 7.5$.

To measure ${ }^{125} \mathrm{I}-\mathrm{WGA}$ binding to islet-cell fractions, the isolated islets from 13 rats were incubated for $30 \mathrm{~min}$ at room temperature with $1.14 \times 10^{-8} \mathrm{~mol} / 1{ }^{125} \mathrm{I}-$ WGA $(481 \mathrm{MBq} / \mathrm{mg})$ in $1 \mathrm{ml}$ of Krebs-Ringer bicarbonate (KRB) buffer, $\mathrm{pH} 7.4$, containing $0.5 \%$ bovine serum albumin. The incubation was terminated by washing the islets 3 times with $3 \mathrm{ml}$ of ice-cold KRB per wash. The islets were then fractionated according to the protocol described above (Fig. 1) and the results were expressed as ${ }^{125} \mathrm{I}$ WGA $\mathrm{cpm} / \mu \mathrm{g}$ protein.

Succinic and NADH Cytochrome-C Reductase. The microsomal content of all fractions was measured using the NADH cytochrome-C reductase assay described by Dallner et al. [10]. Mitochondrial distribution was evaluated using a succinic cytochrome-C reductase assay [11]. These activities were expressed as nmol cytochrome- $\mathrm{C}$ reduced/min per $\mathrm{mg}$ protein using the extinction coefficient of $18.5 \mathrm{mmol}^{-1} \cdot \mathrm{I} \cdot \mathrm{cm}^{-1}$.

Immunoreactive Insulin. Distribution of immunoreactive insulin (IRI) throughout the islet-cell fractions was determined in acidethanol extracts of each fraction by the insulin assay method of Wright et al. [12], using purified rat insulin as the standard. The insulin content of each fraction was expressed as $n g$ insulin $/ \mu \mathrm{g}$ protein.

Microscopy. Morphologic evaluation of the composition of each fraction was accomplished by phase-contrast or electron microscopy or both. After the final centrifugation, the fractions collected from the sucrose gradient were fixed in the cellulose nitrate tubes by adding $0.5 \mathrm{ml} 2 \%$ cacodylate buffered glutaraldehyde $(\mathrm{pH} 7.4$, $4^{\circ} \mathrm{C}$ ) and allowing the tubes to stand overnight at room temperature. The fixed fractions were transferred to a $0.4 \mathrm{ml} \mathrm{Beckman}$ Microfuge- $\mathrm{B}$ tube so that the reagents used for fixation and sample preparation could easily be changed by pelleting the fixed material after each step. The fractions were post-fixed for $1 \mathrm{~h}$ in $1 \%$ osmium tetroxide, rinsed in phosphate buffer, dehydrated in ethanol, and embedded in Spurr resin [13]. Thin sections, stained with uranyl acetate and lead citrate, were examined in a Philips EM 200 electron microscope.

\section{Measurement of Calcium Binding}

Modifications in Plasma Membrane Isolation. EDTA was omitted from the centrifugation buffer in order to prevent possible interference in the calcium binding assay due to the presence of residual EDTA in the plasma membrane fraction. Therefore, when preparing plasma membranes for calcium binding experiments, $P 1$ was resuspended and briefly sonicated in order to thoroughly disperse the preparation for density gradient centrifugation. $\mathrm{P} 1$ was resuspended in $0.5 \mathrm{ml}$ of homogenization buffer and sonicated for $2 \mathrm{sec}$ ( 30 watts; 20,000 cycles $/ \mathrm{sec}$ ) while surrounded by an ice bath. The sonicate was then centrifuged at $600 \times \mathrm{g}$ for $5 \mathrm{~min}$ and the supernatant was combined with $\mathrm{S} 1$. This modification did not affect the purity or yield of the plasma membrane preparation, as determined by 5'-nucleotidase activity and protein recovery. Morphologic evaluation of the various fractions by phase-contrast and electron microscopy indicated a normal appearance of the organelles.

Calcium Binding Assay. Calcium binding was measured in freshly prepared plasma membrane vesicles. The assay buffer contained $25 \mathrm{mmol} / 1 \mathrm{Tris}, \mathrm{pH} 7.0,0.1 \mathrm{~mol} / 1 \mathrm{KCl}, 4,0 \mu \mathrm{mol} / 1$ to $2.5 \mathrm{mmol} / 1$ $\mathrm{CaCl}_{2}$ and $37 \mathrm{kBq}{ }^{45} \mathrm{CaCl}_{2}$. The calcium content of the buffer was determined by atomic absorption spectroscopy. Incubations were conducted in polystyrene tubes (Falcon No. 2038) at $37^{\circ} \mathrm{C}$ with constant shaking $(25 \mathrm{cycles} / \mathrm{min}$ ). The assays were initiated by the addition of 1-2 $\mu \mathrm{g}$ of plasma membrane protein (in $5 \mu \mathrm{l}$ of buffer without ${ }^{45} \mathrm{CaCl}_{2}$ ) to $95 \mu \mathrm{l}$ of prewarmed buffer. At the appropriate intervals, the assay was stopped by suction filtration (Gelman 4204 filter funnel) of $90 \mu \mathrm{l}$ of the incubation mixture through cellulose filters (HAWP, Millipore Corp., Bedford, MA) and immediately washed twice with $7.5 \mathrm{ml}$ of $0.25 \mathrm{~mol} / 1$ sucrose to remove unbound ${ }^{45} \mathrm{Ca}^{2+}$. Appropriate blank tubes without plasma membranes were assayed to correct for non-specific binding of ${ }^{45} \mathrm{Ca}^{2+}$ to the filters. The filters were dried in liquid scintillation vials, covered with $10 \mathrm{ml}$ of scintillation mixture (Omniflour, New England Nuclear, Boston, MA) and counted. Determination of total radioactivity in the buffer was made by counting 4 to $6 \mu l$ samples on a filter. The results were expressed as picomoles of calcium bound per microgram of protein. The protein content of the plasma membrane fraction was measured by the method of McKnight [14], using bovine serum albumin as the standard.

\section{Results}

\section{Plasma Membrane Isolation}

Assessment of the islet-cell fractionation procedure was made by measuring the distribution of biochemical markers in the various fractions (Table 1). Approximately $12 \%$ of the total homogenate 5 '-nucleotidase activity and approximately $1 \%$ of the total protein were recovered in $\mathrm{B} 1$, the plasma membrane fraction. The binding of ${ }^{125} \mathrm{I}-\mathrm{WGA}$ per unit protein was enhanced more than 11-fold in B1 compared to the homogenate and the recovery of bound ${ }^{125} \mathrm{I}-$ WGA in $\mathrm{B} 1$ was $5.0 \%$ of the total in the homogenate. The mean enrichment of $5^{\prime}$-nucleotidase specific activity in $\mathrm{B} 1$ was $10.2 \pm 2.4$ fold $(\mathrm{n}=6)$. In addition, there was $1 \%$ or less recovery of each of the other enzymatic markers in B1, and no or only slight 


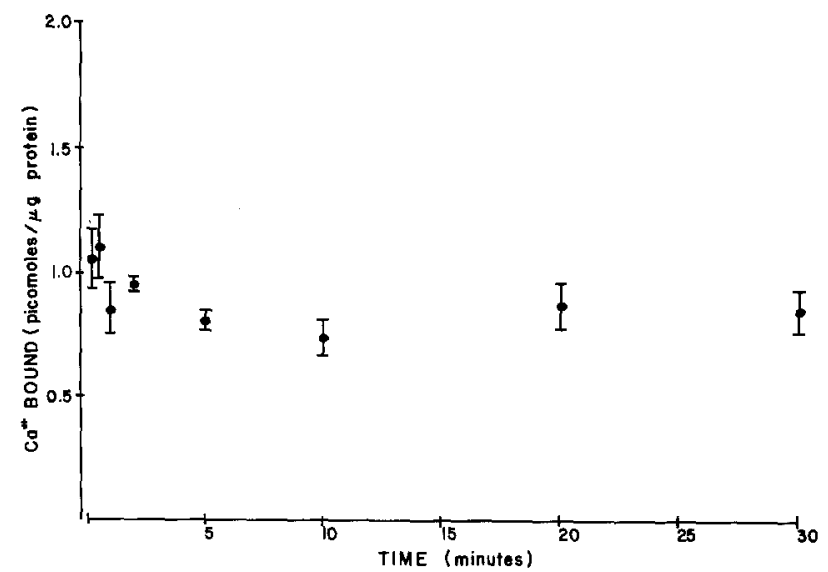

Fig. 2. Time course of calcium binding. Calcium binding was measured by the procedure outlined in "Materials and Methods". The total calcium concentration was $7.0 \mu \mathrm{mol} / 1$. In each of three experiments all eight time points were determined in duplicate. Each point represents the mean \pm SEM of 6 observations

enrichment of their specific activities as compared to homogenate values. By electron microscopy, fraction B1 contained an abundant population of smooth membranous vesicles with little contamination by heavier organelles.

\section{Preliminary Characterization of Calcium Binding}

Bound calcium demonstrated a linear dependence on added plasma membrane protein over a range of 0.4 to $4.3 \mu \mathrm{g}$ of protein per assay tube in the presence of $7 \mu \mathrm{mol} / 1$ total calcium. An equilibrium level of calcium binding was achieved within $15 \mathrm{sec}$ and this level of binding was maintained for at least $30 \mathrm{~min}$ (Fig. 2). All subsequent equlibrium binding experiments were conducted by using a 20 -min incubation period.

Calcium binding was inhibited $50 \%$ by the addition of $18 \mathrm{mmol} / 1 \mathrm{LaCl}_{3}$ to the incubation medium which contained $4 \mu \mathrm{mol} / 1$ total calcium. $\mathrm{La}^{3+}$ has a very high positive charge density and should have a greater electrostatic attraction for negatively charged binding sites than $\mathrm{Ca}^{2+}[15]$. The high $\mathrm{La}^{3+}$ concentration required to cause a $50 \%$ inhibition of calcium binding suggests that this binding is not a non-specific charge phenomenon. Similar results have been observed in other studies [16].

The dependence of calcium binding on the total calcium concentration in the incubation medium is shown in Figure $3 \mathrm{~A}$. Equilibrium calcium binding in the isolated islet-cell plasma membrane vesicles was concentration-dependent and saturable. Calcium binding reached a plateau value of approximately 27 picomol $/ \mu \mathrm{g}$ protein between 1.0 and $2.5 \mathrm{mmol} / \mathrm{l}$ total calcium. Scatchard analysis [17] of a representative
S. P. Naber et al.: Calcium Binding in Islet-cell Plasma Membranes
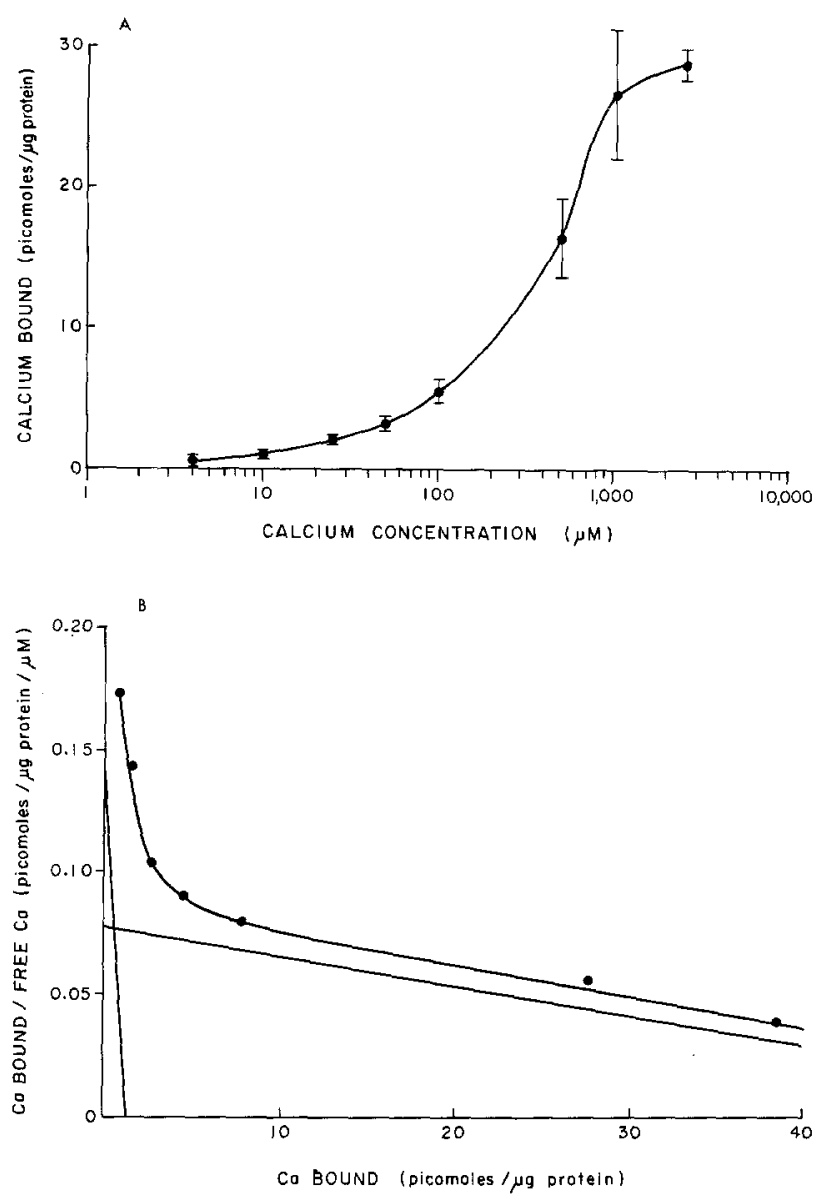

Fig. 3. A Dependence of calcium binding on calcium concentration. Calcium binding measurements were performed following a 20-min incubation as described in "Materials and Methods". The incubation medium contained from $4.0 \mu \mathrm{l} / \mathrm{l}$ to $2.5 \mathrm{mmol} / 1$ total calcium. The results are expressed as the mean \pm SEM of 4 to 12 observations. B Scatchard plot of a representative calcium binding experiment. The experiment (included in $3 \mathrm{~A}$ ) was conducted in a medium containing $4.0 \mu \mathrm{mol} / \mathrm{l}$ to $1.0 \mathrm{mmol} / 1$ total calcium. The curve was analyzed by the hand estimation method of Rosenthal (18) which is used for data with a limited number of observations. The affinity constants $\left(\mathrm{K}_{\mathrm{a}}\right)$ and maximum binding capacities $\left(\mathrm{B}_{\max }\right)$ were determined from the slope and extrapolated $x$-intercept of each straight line

experiment resulted in a curvilinear plot (Fig. 3B), indicating the existence of more than one order of calcium binding sites. The affinity constants $\left(\mathrm{K}_{\mathrm{a}}\right)$ and maximum binding capacities $\left(\mathrm{B}_{\max }\right)$ were determined directly from the Scatchard plot by the method of Rosenthal [18]. $\mathrm{K}_{\mathrm{a}}$ was $1.14 \times 10^{5} \mathrm{M}^{-1}$ for the high affinity site and $1.17 \times 10^{3} \mathrm{M}^{-1}$ for the low affinity site. The corresponding $B_{\max }$ values were 1.2 and $64.8 \mathrm{picomol} / \mu \mathrm{g}$. protein for the high and low affinity sites, respectively.

In order to confirm the presence of two classes of calcium binding sites in these islet-cell plasma membrane preparations, a kinetic analysis of the dissociation of bound ${ }^{45} \mathrm{Ca}^{2+}$ was also conducted. In these 


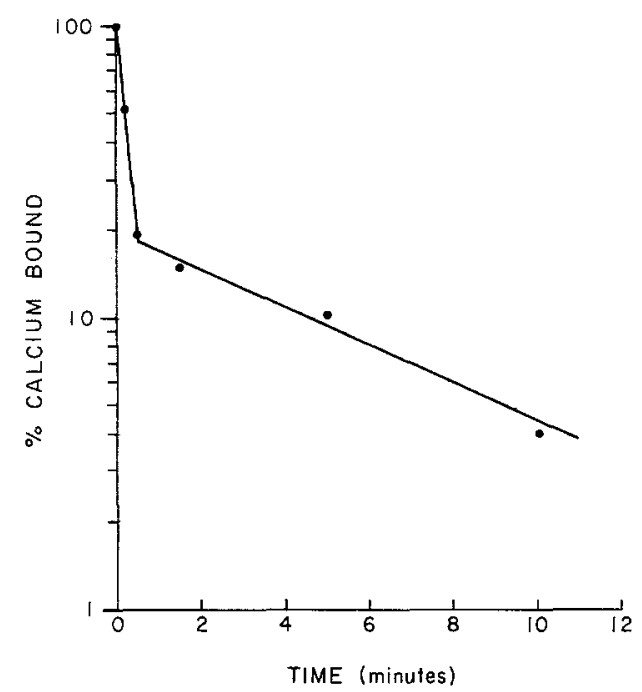

Fig. 4. Dissociation of ${ }^{45} \mathrm{Ca}^{2+}$ from islet-cell plasma membranes. The membrane vesicles were incubated for $20 \mathrm{~min}$ in the presence of $10 \mu \mathrm{mol} / 1$ total calcium $\left(37 \mathrm{kBq}{ }^{45} \mathrm{CaCl}_{2}\right)$. At the completion of this period, an aliquot was removed and filtered to determine the $100 \%$ level of calcium binding. Unlabelled calcium $(10 \mathrm{mmol} / \mathrm{l})$ was then added to the membranes and samples were taken for assay by filtration at $15,30,90 \mathrm{~s}, 5$ and $10 \mathrm{~min}$. The results are expressed as the means of duplicate observations

experiments, calcium binding to the membrane vesicles was allowed to reach equilibrium and then excess $(10 \mathrm{mmol} / 1)$, unlabelled $\mathrm{CaCl}_{2}$ was added in order to displace the bound ${ }^{45} \mathrm{Ca}^{2+}$. The results of these experiments revealed the presence of a biphasic calcium dissociation curve (Fig. 4). Approximately $70 \%$ of the calcium bound at equilibrium was dissociated from the membrane vesicles in the initial, rapid phase and, presumably reflected that from the high affinity sites.

The addition of $20 \mathrm{mmol} / \mathrm{l} \mathrm{D}$-glucose to the assay buffer did not affect the amount of calcium bound in the presence of $7 \mu \mathrm{mol} / 1$ total calcium. The value was $2.23 \pm 0.09 \mathrm{picomol} / \mu \mathrm{g}$ protein $(\mathrm{n}=20)$ in the presence of $20 \mathrm{mmol} / \mathrm{l} \mathrm{D}$-glucose and was $2.07 \pm 0.11$ $\mathrm{picomol} / \mu \mathrm{g}$ protein $(\mathrm{n}=20)$ in the absence of $\mathrm{D}$ glucose.

\section{Discussion}

The plasma membrane-enriched fraction obtained by the procedure detailed in this study was comparable to plasma membrane fractions obtained from other endocrine and neuroendocrine cell types with regard to enrichment and recovery of $5^{\prime}$-nucleotidase activity, as well as morphologic criteria [19-22]. In particular, the present preparation is equivalent to the islet-cell plasma membrane preparation of Lernmark et al. [23] in terms of protein recovery in the plasma membrane fraction, recovery and enrichment of both bound ${ }^{125} \mathrm{I}$-WGA and $5^{\prime}$-nucleotidase activity.

Calcium binding to the islet-cell plasma membranes was concentration-dependent and saturable. When analyzed by both equilibrium and kinetic methods, calcium binding consisted of at least two apparent classes of binding sites. The location of the calcium binding sites with respect to the orientation of the plasma membrane vesicles, was not determined. The results are in accord with the observation of calcium binding to two distinct classes of sites in isolated plasma membrane systems of adipocytes [16], brain [24], liver [25], myocardium [26], placenta [27], erythrocytes [28] and skeletal muscle [29]. The association constants for the high $(1.14 \times$ $\left.10^{5} \mathrm{M}^{-1}\right)$ and low $\left(1.17 \times 10^{3} \mathrm{M}^{-1}\right)$ affinity sites in the islet-cell plasma membranes fall within the range of values reported for these other plasma preparations. Furthermore, the maximum binding capacities of the islet-cell plasma membrane binding sites $(1.2$ picomoles $/ \mu \mathrm{g}$, high affinity; 64.8 picomoles $/ \mu \mathrm{g}$, low affinity) are quite similar to those reported for adipocyte plasma membranes ( 6.6 and 36.5 picomoles/ug; high and low affinity, respecitvely) [16]. In addition, the dissociation rate constant for the high affinity site of the islet-cell membranes, as determined by kinetic analysis, was $2.8 \times 10^{-3} \mathrm{sec}^{-1}$, which agrees closely with the high affinity dissociation rate constant of 9.2 $\times 10^{-3} \mathrm{sec}^{-1}$ reported for adipocyte plasma membranes [16]. It appears, therefore, that the preliminary calcium binding data obtained for the islet-cell plasma membranes is consistent with similar data for well-established plasma membrane preparations from other cell types.

Binding measurements are made without added ATP and, as demonstrated here, reach equilibrium within seconds. Therefore, the membrane-associated ${ }^{45} \mathrm{Ca}^{2+}$ measured here represents calcium accumulated by simple binding rather than by processes such as active transport or diffusion. These have a much longer time course and result in substantially greater calcium accumulation [30]. Recently, a high affinity $\mathrm{Ca}^{2+}$-ATPase has been indentified in islet-cell plasma membranes prepared by the present technique [31]. This enzyme appears to be identical to a $\mathrm{Ca}^{2+}$-ATPase described in adipocyte plasma membranes [32] and may represent a $\mathrm{Ca}^{2+}$ extrusion pump in the islet-cell plasma membrane.

At present it is difficult to propose a specific physiological role for calcium binding in the islet-cell plasma membrane. Indirect evidence using chlorotetracycline suggests that regulation of calcium homeostasis by the beta-cell plasma membrane may be an integral step in insulin secretion [33]. Physiological concentrations of insulin alter the capacity for the 
adipocyte plasma membrane [34] and the sarcolemma [35] to bind calcium. By analogy, it is possible that alterations in calcium binding may occur in the beta-cell plasma membrane in association with insulin secretion.

Acknowledgements. The authors wish to thank Dr. Ronald L. Gingerich, Department of Pediatrics, Washington University, for assistance in iodinating the wheat germ agglutinin. This work was supported by NIH grants AM06181 and AM11892. S.P.N. was a recipient of postdoctoral fellowships from the Juvenile Diabetes Foundation and from the NIH (AMO5398).

\section{References}

1. Curry DL, Bennett LL, Grodsky GM (1968) Requirements for calcium ion in insulin secretion by the perfused pancreas. Am J Physiol 214: 174-178

2. Hellman B, Sehlin J, Täljedal I-B (1976) Calcium and secretion: distinction between two pools of glucose-sensitive calcium in pancreatic islets. Science 194: 1421-1423

3. Schafer H-J, Kloppel G (1974) The significance of calcium in insulin secretion. Virchows Arch [Pathol Anat] 362: 231-245

4. Ravazzola M, Malaisse-Lagae F, Amherdt M, Perrelet A, Malaisse WJ, Orci L (1976) Patterns of calcium localization in pancreatic endocrine cells. J Cell Sci 21: 107-117

5. Rubin RP (1970) The role of calcium in the release of neurotransmitter substances and hormones. Pharmacol Rev 22: $389-428$

6. Rasmussen H (1970) Cell communication, calcium ion, and cyclic adenosine monophosphate. Science 170: 404-412

7. Shibata A, Ludvigsen CW, Naber SP, McDaniel ML, Lacy PE (1976) Standardization of a digestion-filtration method of isolation of pancreatic islets. Diabetes 25: 667-672

8. Lowry OH, Rosebrough NJ, Farr LA, Randall RJ (1951) Protein measurement with the Folin reagent. J Biol Chem 193: 265-275

9. Avruch J, Wallach DFH (1971) Preparation and properties of plasma membrane and endoplasmic reticulum fragments from isolated rat fat cells. Biochim Biophys Acta 233: 334-347

10. Dallner G, Siekovitz P, Palade GE (1966) Biogenesis of endoplasmic reticulum and membranes II. Synthesis of constitutive microsomal enzymes in developing rat hepatocyte. J Cell Biol 30: $97-117$

11. Fleischer S, Fleischer B (1967) Removal and binding of polar lipids in mitochondria and other membrane systems. In: Estabrook RW, Pullman ME (eds) Methods in enzymology, vol X. Academic Press, New York, p 406-433

12. Wright PH, Makulu PR, Vichick D, Sussman KE (1971) Insulin immunoassay by back-titration; some characteristics of the technique and the insulin precipitant action of alcohol. Diabetes $20: 33-45$

13. Spurr AR (1969) A low-viscosity epoxy resin embedding medium for electron microscopy. J Ultrastruct Res $26: 31-43$

14. McKnight SG (1977) A colorimetric method for the determination of submicrogram quantities of protein. Anal Biochem 78: 86-92

15. Lettvin JY, Prickard WF, McCulloch WS, Pitts W (1964) A theory of passive ion flux through axon membranes. Nature 202: 1338-1339

16. McDonald JM, Bruns DE, Jarett L (1976) Characterization of calcium binding to adipocyte plasma membranes. J Biol Chem 251: 5345-5351

17. Scatchard G (1949) The attraction of proteins for small molecules and ions. Ann NY Acad Sci 51: 660-675

18. Rosenthal HD (1967) A graphic method for the determination and presentation of binding parameters in a complex system Anal Biochem 20: 525-532

19. Poirier G, DeLean A, Pelletier F, Lemay A, Labrie F (1974) Purification of adenohypophyseal plasma membranes and properties of associated adenylate cyclase. J Biol Chem 249: 316-322

20. Poirier G, Labrie F, Lemay A, Dupont A, Savary M, Pelletier G (1977) Purification of plasma membrane fractions from the bovine pars intermedia and neurohypophyseal lobe and properties of associated adenylate cyclase. Can J Biochem 55: $555-566$

21. Wolff J, Jones AB (1971) The purification of bovine thyroid plasma membranes and the properties of membrane-bound adenyl cyclase. J Biol Chem 246: 3939-3947

22. Wilson SP, Kirshner N (1976) Isolation and characterization of plasma membranes from the adrenal medulla. J Neurochem 27: $1289-1298$

23. Lernmark A, Nathans A, Steiner DF (1976) Preparation and characterization of plasma membrane enriched fractions from rat pancreatic islets. J Cell Biol 71: 606-623

24. Hemminki K (1974) Calcium binding to brain plasma membranes. Biochim Biophys Acta 363: 202-210

25. Shlatz L, Marinetti GV (1972) Calcium binding to the rat liver plasma membrane. Biochim Biophys Acta 290: 70-83

26. Krause E-G, Well H, Schapke B, Wollenberger A (1975) Cyclic AMP-enhanced protein phosphorylation and calcium binding in a membrane-enriched fraction from myocardium. In: Drummond GI, Greenyard P, Robison GA (eds) Advances in cyclic nucleotide research, vol 5. Raven Press, New York, p $473-490$

27. Shami Y, Messer HH, Copp DH (1974) Calcium binding to placental plasma membranes as measured by rate of diffusion in a flow dialysis system. Biochim Biophys Acta 339: 323-333

28. Sato T, Fujii T (1974) Binding of calcium and magnesium ions to human erythrocyte membranes. Chem Pharm Bull (Tokyo) 22: $368-374$

29. Madeira VMC, Carvalho AP (1972) Interaction of cations and local anesthetics with isolated sarcolemma. Biochim Biophys Acta 266: 670-683

30. Moore L, Fitzpatrick DF, Chen TS, Landon EJ (1974) Calcium pump activity of the renal plasma membrane and renal microsomes. Biochim Biophys Acta 345: 405-418

31. McDonald JM, Pershadsingh HA, Bry CG, McDaniel ML, Lacy PE (1980) Identification of a high affinity $\mathrm{Ca}^{2+}$-ATPase in plasma membranes from pancreatic islets. Fed Proc 39: 380 (abstr)

32. Pershadsingh HA, McDonald JM (1979) Direct addition of insulin inhibits a high affinity $\mathrm{Ca}^{2+}-\mathrm{ATPase}$ in isolated adipocyte plasma membranes. Nature 281: 495-497

33. Taljedal I-B (1978) Chlorotetracycline as a fluorescent $\mathrm{Ca}^{2+}$ probe in pancreatic islet cells, methodological aspects and effects of alloxan, sugars, methylxanthines and $\mathrm{Mg}^{2+}$. J Cell Biol 76: 652-674

34. McDonald JM, Bruns DE, Jarett L (1976) Ability of insulin to increase calcium binding by adipocyte plasma membranes. Proc Natl Acad Sci USA 73: 1542-1546

35. Cheng LC, Rogus EM, Zierler K (1978) Specific D-glucose transport in sarcolemma vesicles. Biochim Biophys Acta 513: 141-155

Received: May 27, 1980

Dr. S. P. Naber

Elliott P. Joslin Research Laboratory

Harvard Medical School

One Joslin Place

Boston, MA 02215

USA 